\title{
Population vulnerability and disaster risk reduction: A situation analysis among the landslide affected communities in Kerala, India
}

\section{Sunil Damodaran Santha}

Department of Social Work, Amrita Vishwa Vidyapeetham (Deemed University),

Kollam, Kerala, India. sunilds@gmail.com

\section{Ratheeshkumar Kanjirathmkuzhiyil Sreedharan \\ Department of Social Work \\ Amrita Vishwa Vidyapeetham (Deemed University), Kollam, Kerala, India. ratheeshlo@gmail.com}

\section{ABSTRACT}

Landslides affect at least $15 \%$ of the land area of India, exceeding 0.49 million $\mathrm{km} 2$. Taking the case of landslide affected communities in the state of Kerala in India, this paper demonstrates that the focus has seldom been placed on assessing and reducing vulnerability. From the perspective of political economy, this paper argues that vulnerability reduction has to be the main priority of any disaster risk reduction programme. This paper also demonstrates that the interactions between ecological and social systems are usually complex and non-linear in nature. In contrast, interventions to tackle landslide risks have followed a linear course, assuming that one hazard event acts independently of another. The key findings of the study show that lack of access to political power, decision making, and resources, insecure livelihoods, environmental degradation, and ineffectiveness of the state approach to disaster risk reduction are some of the major factors that lead to increasing vulnerability. Qualitative in nature, the primary data were collected through in-depth interviews with people from different groups such as farmers affected by the landslides and secondary floods, men and women living in the temporary shelter, government representatives involved in relief activities, health authorities, and elected representatives.

\section{KEYWORDS}

Vulnerability, landslide, environment, livelihood, multiple hazards

\section{Introduction}

Disasters due to floods, drought, fires, tsunamis, landslides and biological hazards could intensify their magnitude due to historical, social, economic, political and environmental factors. A significant feature of today's disaster risk reduction process is that it does not take environmental imbalances into account and neither the co-existing hazards nor their likeliness to generate new kinds of disaster risk. Though incidences and losses related to natural hazards 
have increased in the recent past, efforts have mainly focused on impact assessment, immediate relief and some structural mitigation measures. This paper argues that vulnerability reduction has to be the main priority of any disaster risk reduction programme. Taking the case of landslide-affected communities in the Kozhikode district in Kerala, this paper shows that the focus has seldom been on assessing and reducing vulnerability.

Landslides affect at least $15 \%$ of the land area of India, exceeding 0.49 million $\mathrm{km}^{2}$. These are not only prominent in geo-dynamically active fields such as the Himalayas, but also in relatively stable domains such as the Western Ghats in South India. Research on landslide and other geohydrological hazards has mostly focused on hazard-oriented, purely technical solutions. Vulnerability reduction has seldom been a focus of these approaches (Lewis, 1999). On the other hand, in the past decade, different conceptual frameworks have been presented and debated. These debates are part of a process that presumes that vulnerability reduction is very essential for disaster risk reduction and building resilience. In this regard Wisner et al. (2004) have asserted that disaster risk has to be understood as a compound function of the natural hazard and the number of people, characterised by their varying degrees of vulnerability to that specific hazard, who occupy the space and time of exposure to the hazard event.

However, it is a paradox that no precise and universal definition of vulnerability exists and different authors have used the term differently. One of the most commonly accepted definitions of vulnerability is that of the International Strategy for Disaster Risk Reduction. It defines vulnerability as 'the conditions determined by physical, social, economic, and environmental factors or processes, which increase the susceptibility of a community to the impact of hazards (UNISDR, 2004). In a similar vein, Cannon et al. (2003:5) have described vulnerability as a set of characteristics that include a person's (i) initial wellbeing (nutritional status, physical and mental health), (ii) livelihood and resilience (assets and capital, income, and qualifications), (iii) self-protection (capability and willingness to build a safe home, use a safe site), (iv) social protection (preparedness and mitigation measures, and (v) social and political networks and institutions such as social capital and other features in the institutional environment. The political economy perspectives on disaster risk reduction, especially from the works of Wisner et al. (2004), have contributed considerably to the in-depth analysis of population vulnerability to disasters. A prominent model in this regard is the Pressure and Release Model (PAR).

The Pressure and Release (PAR) Model views disaster as the intersection of two major forces: those processes generating vulnerability, on the one hand, and the natural hazard event on the other. According to this model, vulnerability can be understood within three progressive levels: namely, root causes, dynamic pressures and unsafe conditions. The root causes are closely linked to the aspect of governance, emphasising the lack of access by vulnerable groups to positions of political power, decision-making structures, and resources. It is also related to prevailing ideologies of dominance, mainly the political and economic systems. The concept of dynamic pressure encompasses all processes and activities that transform and channel the effects of root causes into unsafe conditions, such as rapid urbanisation, deforestation or decline in soil productivity (Wisner et al., 2004:54). 
Root causes imply dynamic pressures that lead to unsafe conditions, which in turn are specific forms in which human vulnerability is revealed and expressed in the temporal and spatial dimension. Unsafe conditions encompass living in dangerous locations, or having livelihoods that are at risk, the absence of local institutions in governance, or having entitlements that are prone to rapid and severe disruption. The lack of disaster preparedness and appropriate risk reduction measures is itself considered as an unsafe condition (Wisner et al., 2004). This paper has carried out its present analysis guided by the PAR model proposed by Wisner et al. (2004).

Disaster situations such as famines, earthquakes, floods and coastal storms, the spread of infectious diseases etc. have been analysed using the PAR model. Analysing the 2002 famine in Malawi, Wisner et al. (2004:131-133) demonstrated that factors such as impoverishment, epidemics, colonial policies and marginalisation, persecution, dispossession, and failure of the state to control staple food prices have accelerated the trigger event. In a similar vein, social scientists have analysed the progression of vulnerability with respect to the recurrent floods in countries such as Bangladesh and India (Wisner et al., 2004:225-235; Santha, 2008). Their studies show that the initial 'pre-hazard' conditions of people and their vulnerability are largely generated from the socio-political and economic systems in which they exist. Examining the trajectories of population vulnerability to emerging epidemics in India, Santha and Bhuvaneswari (2009) have demonstrated that various social, political, and economic factors play a key role in increasing the vulnerability of people to new kinds of diseases. These authors advocate that any attempt towards the prevention and mitigation of public health risks should primarily aim at vulnerability reduction (Santha \& Bhuvaneswari, 2009). In all the above mentioned cases, the PAR model has aided in explaining the significant role of socio-political and economic conditions in the progression of vulnerability.

In addition, the present paper demonstrates that the interactions between ecological and social systems are usually complex and non-linear in nature. On the other hand, interventions to tackle landslide risks have followed a linear course, assuming that one hazard event acts independently of another. Mountain communities in India are exposed to various hazards such as earthquakes, landslides, and drastic environmental changes such as soil degradation, deforestation, declining biodiversity and drought. Regions that are frequented by disasters are also places where environmental degradation proceeds at a rapid pace. In the attempt to cope with the demands of urbanization or integrating with mainstream development, many sensitive ecosystems have been degraded to the point that they are no longer resilient. Neither do they have the ability to withstand natural or man-made disturbances. A healthy natural environment is very often the best protective barrier against many natural disasters. With this assumption, this paper attempts to examine the linkages between mountain eco-system degradation and the progression of vulnerability among the landslide affected communities in Kerala, India. The case of environmental vulnerability demonstrated in this paper is specific to development practices and disasters in Kerala. The arguments presented here are not deduced from risk reduction practices prevailing in other parts of the world.

\section{The field setting}

The region of the Western Ghats of Kerala is identified as one of the major landslide prone areas of the country. Landslides are geo-physical hazards which involve the movement of earth material which is usually dislodged by falling, sliding and flowing under the influence of 
gravity. Different kinds of landslides occur in Kerala such as rock falls, rock slips, and debris flow. However, the most prevalent, recurring and disastrous types of landslides noted in the state are the "debris flows" (Urul pottal). The characteristic pattern of this phenomenon is the swift and sudden down-slope movement of highly water saturated earth matter containing a varied assemblage of debris materials. These materials range from soil particles to boulders, destroying and carrying with them everything that comes across their path. Every year with the onset of monsoons, landslides are reported in the State. Although landslides may have different triggering mechanisms, rainfall resulting in saturated slopes and weakening them to the point of failure, is a major cause of debris flows in the study area.

In the month of July 2009, the monsoons induced severe landslides and associated flooding in the Kozhikode district, affecting more than 10,000 people. Unpublished government records at the district office show that a total of 129 relief camps were opened and around 9678 people were accommodated. This paper is developed on the basis of the primary data collected from the Maruthonkara village, situated in the northern part of the Kozhikode district in Kerala, India. Figure 1 shows a map of the Maruthonkara village in Kozhikode District of Kerala.

Fig1: Location of Maruthonkara village in Kozhikode District

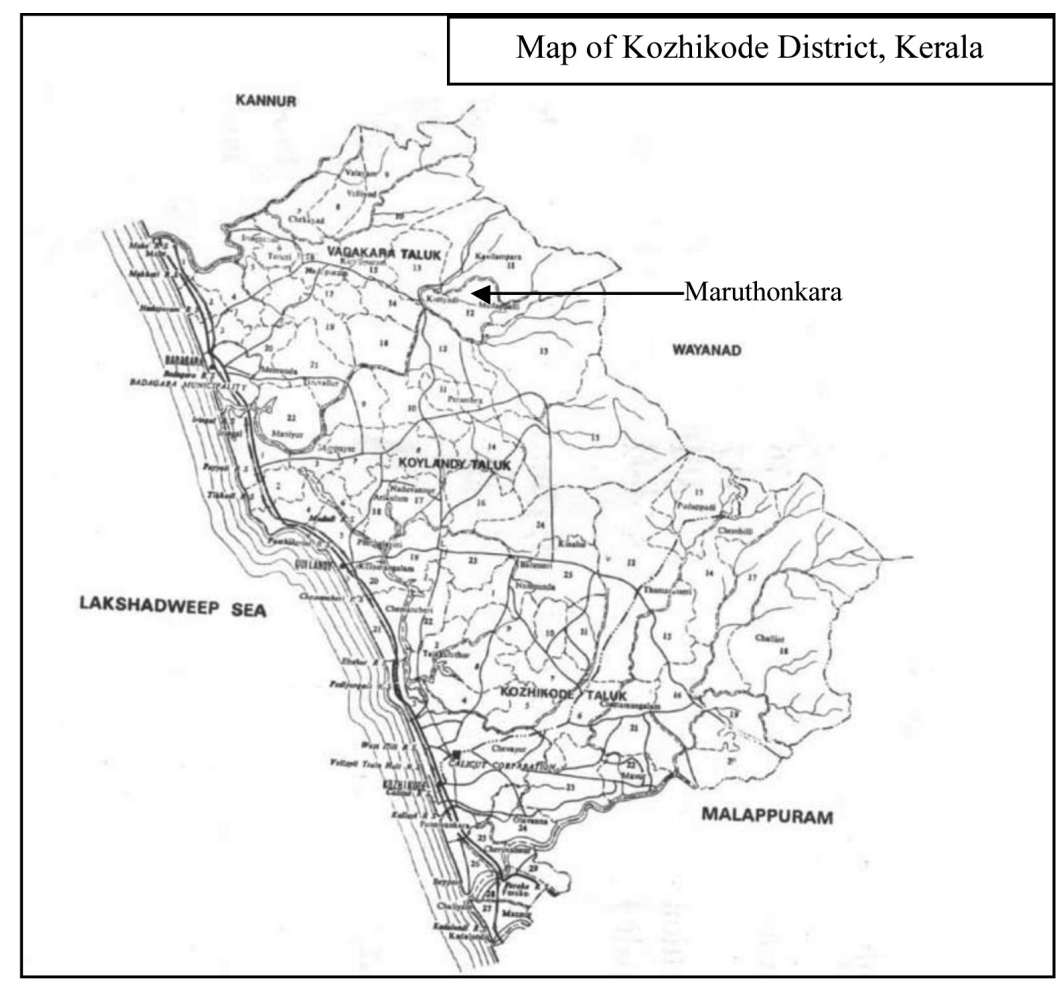

Source: Source: http://www.kkd.kerala.gov.in/district.htm

The place was originally a forest owned by the once powerful aristocratic Nair Family, but was nationalized in the 1950s following the accession of a communist administration in Kerala. 
According to the 2001 India census, Maruthonkara has a population of 18663 among 4000 households, with 9227 males and 9436 females. The population density is 947 per square kilometre, which is comparatively high when compared with other Grama Panchayats in the region (Census of India, 2001). Field visits to the region were carried out within a week of the occurrence of landslides and flooding. Qualitative in nature, the primary data were collected through in-depth interviews with people from different groups such as farmers affected by the landslides and secondary floods, men and women living in the temporary shelter, government representatives involved in the relief activities, health authorities, and elected representatives. These data were substantiated through observations and secondary sources of information.

In July 2009 the heavy rains, which are a regular feature of the monsoons in Kerala, induced severe landslides and associated flooding in the Pashukadavu locale of Maruthonkara Grama Panchayat. Initially, weather commentators had thought that it had been one of the worst monsoons for many years. The monsoons were weak in the month of June. However, they gathered momentum and intensified towards the middle of July and the district recorded the usual quantity of rainfall. Apart from the threat to life they created, the monsoon-induced landslides also destroyed acres of agrarian land and crops. Figures 2 and 3 demonstrate the impact of the landslide on vegetative cover and crops in Pashukadavu. The landslides also damaged infrastructure such as houses, roads and power supply (Figure 4).

Fig 2: This photograph shows how the landslides have uprooted the whole soil and vegetative cover, when compared with the surroundings. The man in the picture is a farmer, whose farm land is at the higher ridge of the landslide affected area.

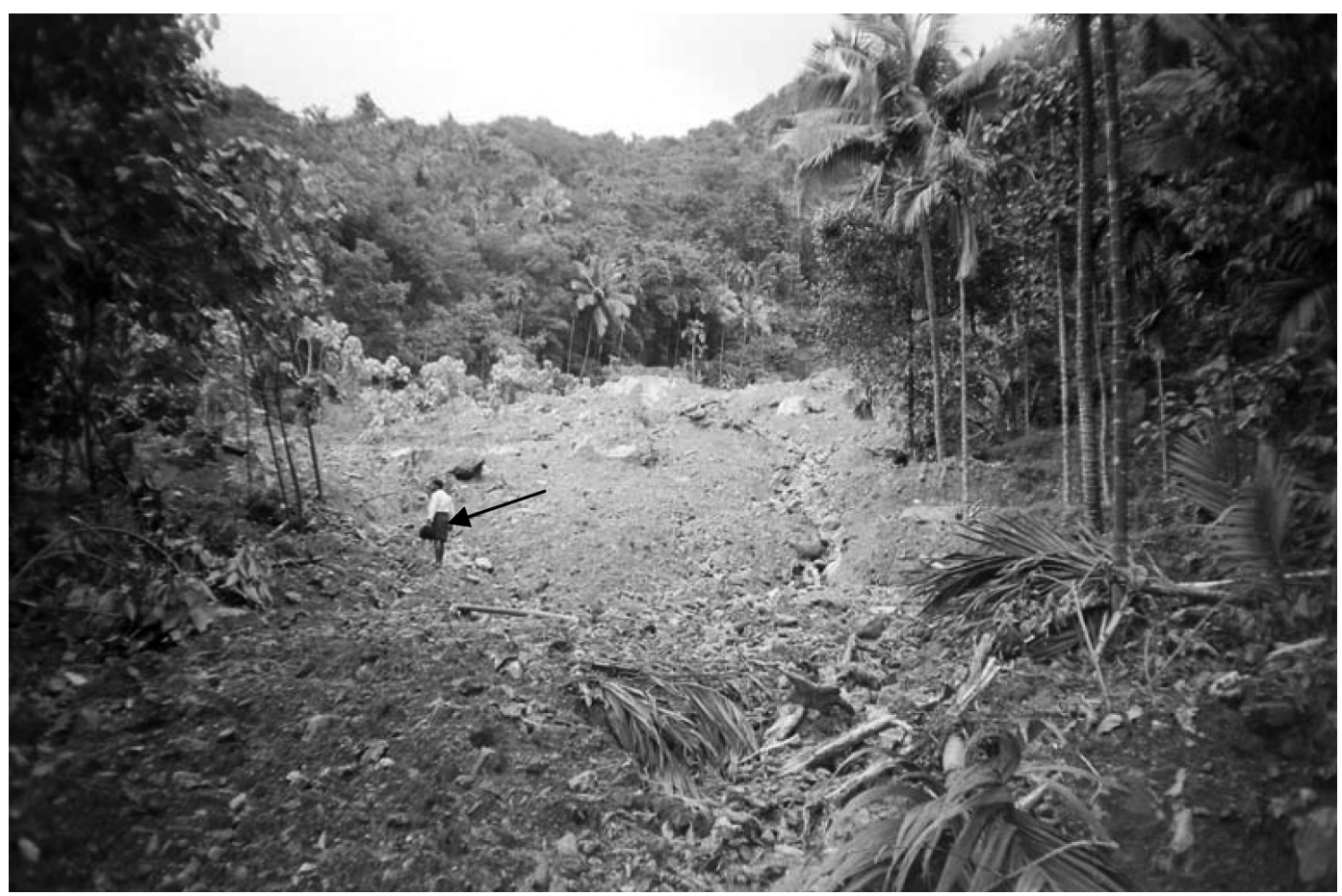


Population vulnerability and disaster risk reduction: A situation analysis among the landslide affected ...

Fig 3: Yet another site of the landslide affected area. The farmers affected are in the frame of the picture.

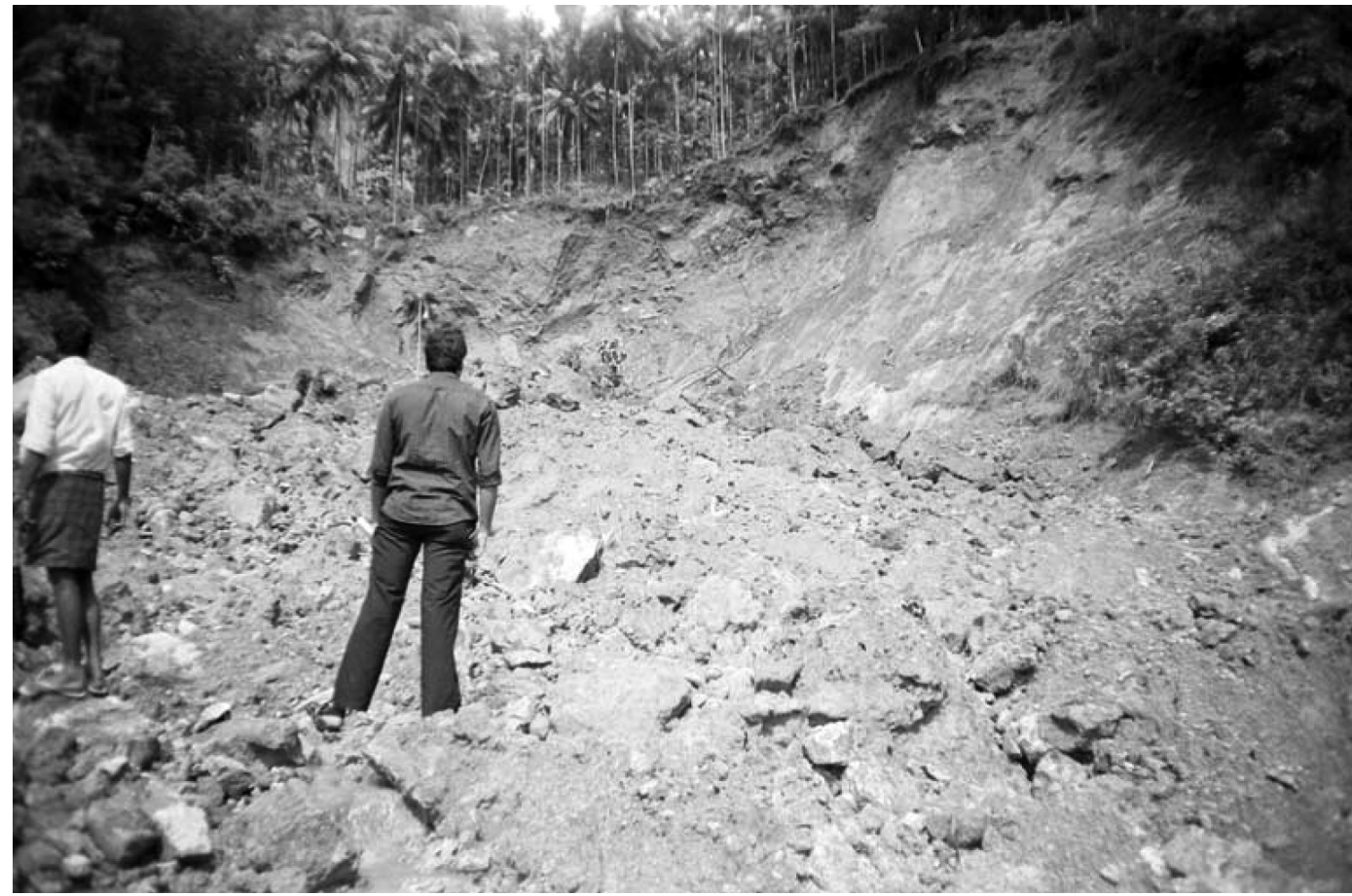

Source: Photos taken during the fieldwork by Sunil D Santha

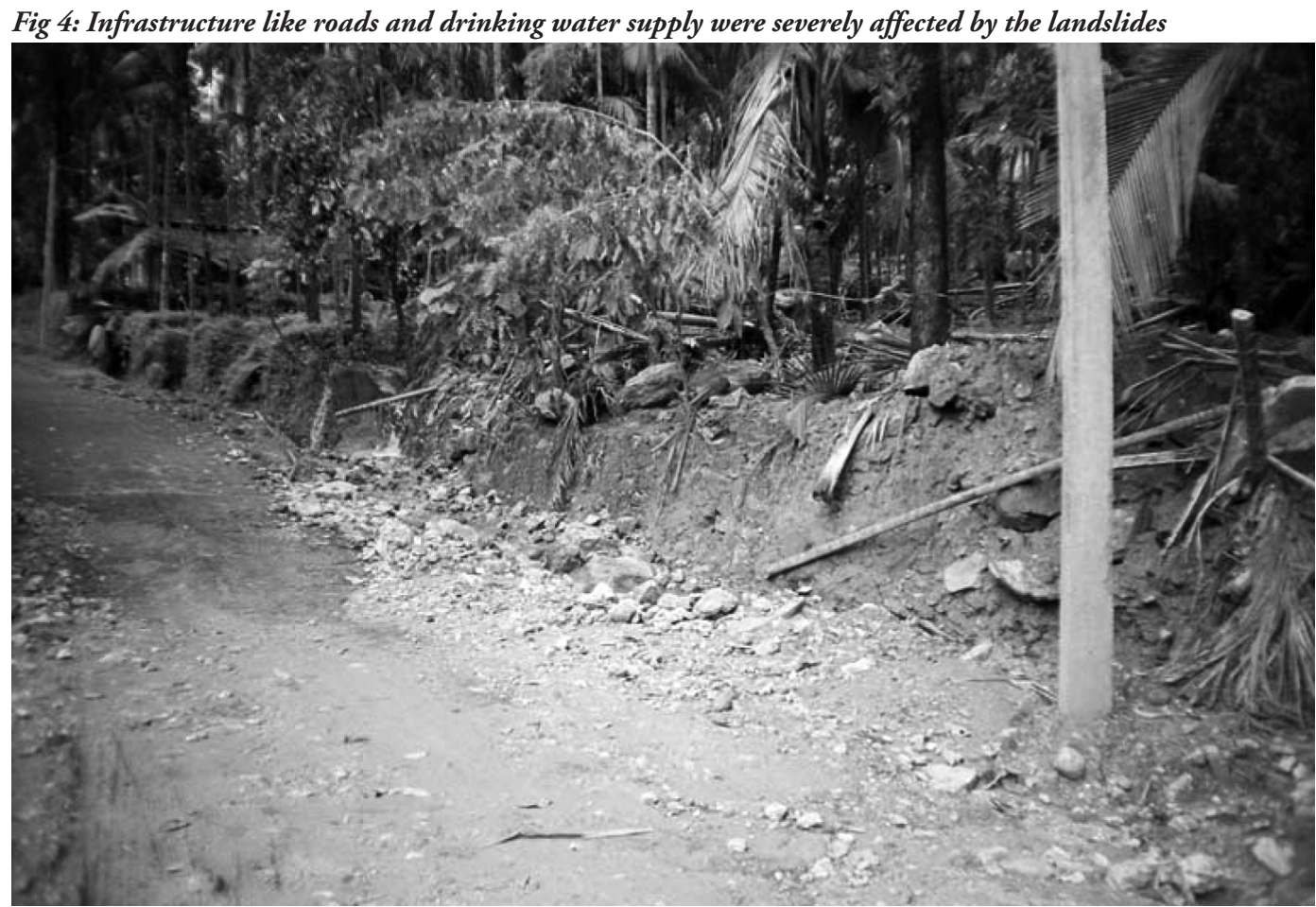

Source: Photos taken during the fieldwork by Sunil D Santha 
In Pashukadavu, immediately after the landslide and associated flooding, the newly constructed emergency shelter was opened to the evacuees. This shelter was the outcome of a series of landslides and consequent loss of life and property in the years 2004 and 2005 respectively. According to local sources, in 2004 there were nine deaths and in 2005 there were six deaths. However, after a gap of three years, landslides occurred on July 18, 2009 at 3.00 AM. Though no loss of life was reported in the two sites, the day-to-day lives of around 36 families were affected, as these families were evacuated to the emergency shelter. The following section will analyse the key factors that have influenced the vulnerability of the local population to natural hazards in the region.

\section{Factors influencing vulnerability to landslides and other secondary hazards}

The preliminary analysis shows that there are a number of factors that have influenced the progression of vulnerability in the region. Some of the most important factors include (i) Lack of access to political power, decision-making, and resources, (ii) insecure livelihoods, (iii) environmental degradation, (iv) globalised trade and unequal exchange of benefits, (v) shortsighted development plans and ineffectiveness of the state approach to disaster risk reduction, (vi) neglect of local knowledge and other coping capacities, and (vii) co-existence of multiple hazards. These are briefly described as follows.

\section{Historical specificity: Lack of access to political power, decision-making, and resources}

Field investigations reveal that a significant proportion of the affected population (more than 30\%) may be classified as either Scheduled Tribes or Scheduled Castes, who are the historically marginalized in the mainstream development processes of the region and the State. Traditionally up to the present, these communities have been isolated in the name of caste and occupational privileges, and have lacked access to political power and decision-making structures. Moreover, their access to resources such as cultivable land and water resources has been limited. While the mainstream communities were able to find livelihoods in the lower plains, these groups had to find alternatives in the upper hills or encroach on the forest lands. Unemployment, both chronic and seasonal, is also widespread (approximately 55\%) among these groups. Around 33 percent of the population affected by the landslide is classified as BPL families (Below Poverty Line).

\section{Insecure livelihoods}

Our primary observation shows that most of the affected population is made up of farmers, agrarian labourers or casual labourers. Most of the farmers are involved in the cultivation of pepper, ginger, turmeric, banana and other plantains, tapioca, food crops, rubber and coconut. People are also involved in alternative livelihoods such as cattle and goat rearing. However, discussions with the villagers have revealed that these farmers are often deprived of fair prices and exploited by intermediaries involved in the trade. It could also be seen that most of the farmers are involved in the cultivation of cash crops that are integrated with the world market. This higher dependence of the population on agriculture and its greater integration with the world market has increased the risk of the population to livelihood uncertainties and casualties such as farmers' suicides (Mohankumar \& Sharma, 2006). 
It was also observed by the same authors that it is the small farmers who are more vulnerable to crop failure and the vagaries of the market such as falling prices, and the higher their proportion in the region, the higher are the casualties (Mohankumar \& Sharma, 2006). For instance crops such as pepper were infected with the quick-wilt disease affecting productivity. The failure in crop production and the lack of access to fair dealings in the market have also landed many farming households in indebtedness. They also find it extremely difficult to pay back the loans from informal sources such as money lenders, friends, and relatives, which they borrowed to grow crops and survive.

\section{Environmental degradation}

Scientific observations regarding the present landslide at Maruthonkara suggested that indiscriminate construction of check dams and rainwater harvesting systems could have triggered the destructive landslides in the region. Scientists have observed that the increase in the catchment area led to the formation of underground reservoirs, which exerted pressure on the dams, causing them to burst. This was clearly evident from the large volume of water racing down the slopes collapsing the downstream check dams, in a destructive chain reaction. However, such an analysis is based on a narrow technocratic perspective. The danger of such orientation is that the solutions provided will also be aimed at addressing the risk through isolated technological interventions rather than vulnerability reduction at all possible levels.

Moreover, the historical analysis of resource use in the region demonstrates that there were significant alterations in land use after the Kerala Land Reforms Act of 1963. Radhakrishnan (1982) has observed that the land reforms were aimed at conferring ownership of land on homestead tenants or the landless agricultural labourers. By the imposition of ceiling laws, the homestead tenants were thus given an opportunity to purchase homestead land from their landowners, and also take possession of the surplus lands. Though the initial objective of the land reforms was to reduce landlessness and abolish tenancy, it also resulted in the isolated conceptualisation of resource utilisation in ecological systems (Krishnan \& George, 2009). For instance, the interconnections among the cultivable land and private forest land were largely ignored. These forests characterised by thick indigenous vegetation were fragmented to individual ownerships and were largely replaced by cash crops. Although there are no studies of root strength for the native forest vegetation in the study area, it can be generally surmised that vegetation plays a crucial role in soil stabilisation, at least to some extent. The cultivation of cash crops at the cost of large quantities of native tree species that firmly held the soil has exposed the terrain to hazards such as soil erosion and landslides (Kumar, 2005). Figure 5 demonstrates how a deeply vegetated hill range has been affected by landslides. It is also striking to note that large parts of the vegetation are plantations and cash crops. Thus, it could be argued that the absence of an ecological perspective in the property rights regime has not only altered the land use practices (Krishnan \& George, 2009) but also may have contributed to the initiation of new kinds of hazards.

A major cause of environmental vulnerability, which is a significant player in the acceleration of hazards into disasters, is the lack of integrated environmental planning. 


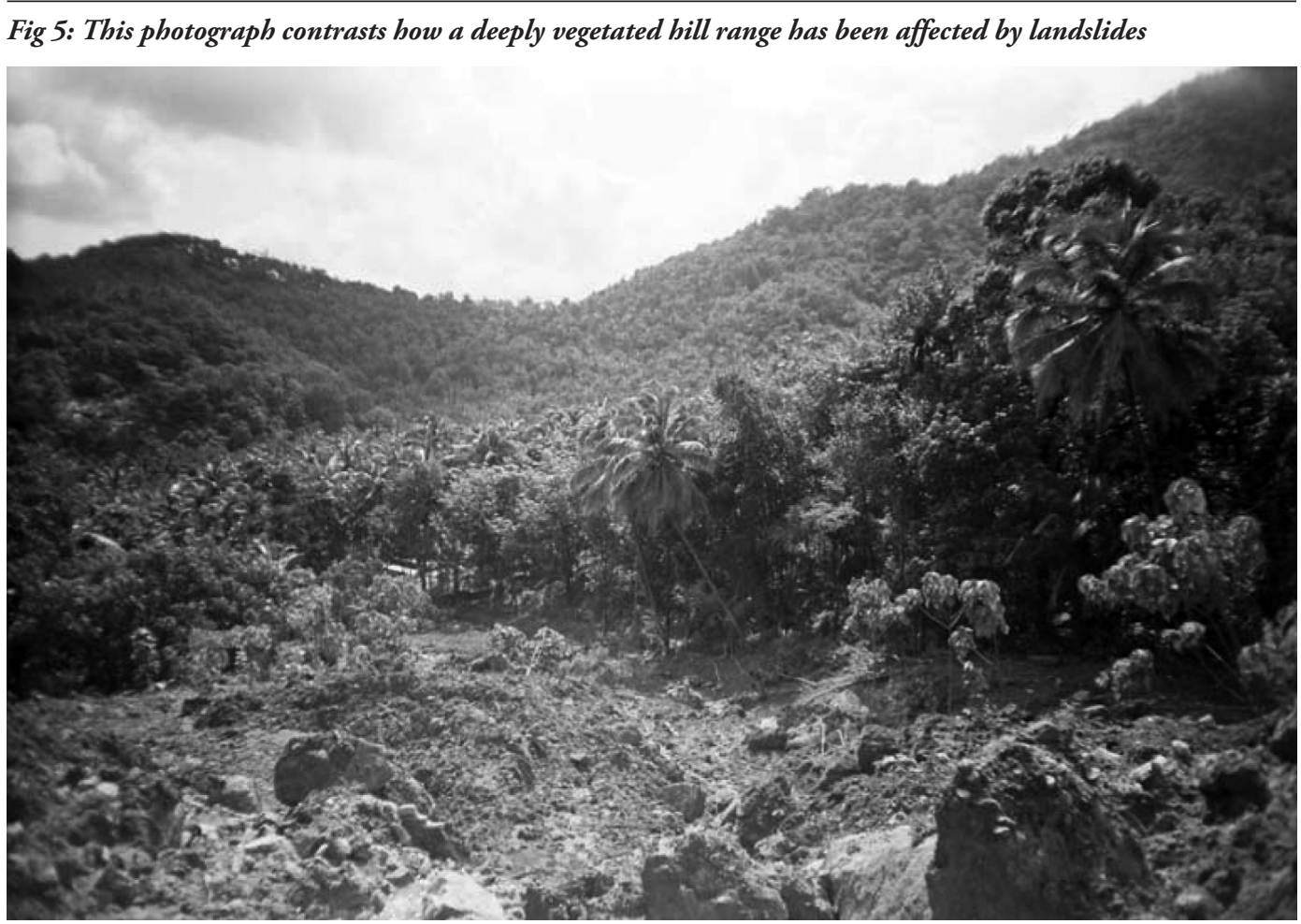

Source: Photos taken during the fieldwork by Sunil D Santha

Environmental resources are today utilised on the basis of individual priorities without much deliberation on the sustainable use of resources. In this regard the Kerala Economic Review 2004 observes that the risk of the population regarding hazards such as landslides has increased due to the rise in population, decline in forest cover, change in agricultural practices and infrastructural development on unstable hill slopes (Government of Kerala, 2004). The report notes that all these factors have resulted in very high saturation levels in the soil, increased pore pressure and lowering of the safety factor. The impact of the above factors is that slope failures occur in the form of landslides (Government of Kerala, 2004).

In a similar vein, it could be understood that the flash floods that followed the landslides in the valleys were mainly due to pitfalls in development planning. Without examining in detail the inter-linkages and functions of different resource systems, constructions were carried out at several river-land interfaces, leading to the destruction of natural drainage systems. Today, many of the connecting channels that were 18 to 20 feet in width have shrunk to a width of 4 to 8 feet, reducing the capacity of the drainages. Most of the waste generated due to natural and man-made causes finally accumulates in the natural drains. Commenting on the flash floods that destroyed many huts on the river bank, the community leader expressed colloquially his perception that "this time, the oceans were not able to absorb the river. Both high tide and encroachment of river banks have resulted in the flooding".

Yet another manifestation of vulnerability is the rise in the population of migrants to the hill ranges. Lack of access to resources and opportunities in the planes have forced many people to 
migrate to the hill ranges. This has also resulted in deforestation and an increase in the population forced to live in hazardous locations.

\section{Ineffectiveness of the State in approaches to disaster risk reduction}

Though there are institutions at the local level (such as the Grama Panchayat) that are vested with the constitutional authority to deal with localised disaster risk reduction, it is a harsh fact that these institutions view the urban centres as their model of development. Rather than depending on locally reliable, ecologically sensitive development plans, the capacities and resources of the community are utilised for replicating the development models followed in the nearby towns and cities. This again results in the re-generation of various development problems rather than vulnerability reduction. For instance, the Gram Panchayat was proposing to concretise the pathways of the landslide, which the local communities did not approve.

These institutions were also unable to execute the relocation of land for the affected households due to ambiguities in the state control over different types of land. Thus there were conflicts between two government departments, namely the Irrigation department and the Revenue department in transferring ownership rights over lands to the affected victims. These complexities have further delayed the relocation of people to safer places.

It is an appreciable fact that the state government has indeed built an emergency shelter in the village following the 2005 landslides. A few houses were also constructed for those people affected then. However, a closer look shows that the emergency shelter has turned out to be a power centre for the state authorities. It was observed that the staff appointed at the shelter had the least sensitivity to the real needs of the people affected by the disaster. Instead of adopting measures to rebuild the resilience of the affected communities, the authorities were imposing their own cultural biases on the affected population. Be it the elderly people or the disabled, they were treated merely as receivers of aid rather than as people with rights to a safe and secure life. One of the striking aspects of the relief team was that most of the government-appointed staff had arrived from far away districts and their interests were to return to their home towns as quickly as possible. Though the physical presence of the institution exists, state intervention thus lacked the necessary orientation and sensitivity towards vulnerability reduction and human rights. This also explains why most of the evacuees were opting to stay with their relatives rather than at the shelter.

\section{Neglect of local knowledge and coping capacities}

Over the years, communities have evolved their own coping strategies and early warning systems. For instance they predict the arrival of landslides by sensing a particular smell emanating from the earth's surface similar to the burning of gunpowder. People also anticipate landslides if there are several new water outlets rising out of the earth's surface. However, these localized early warning systems are often neglected by the authorities concerned and many times seem to be inadequate when compared with the speed and intensity of the hazard. On the other hand, formal interventions of early warning systems are completely absent in the region. The focus is still aimed at providing immediate and short-term disaster relief rather than risk reduction. 


\section{Co-existence of multiple hazards}

An important factor that has contributed to livelihood uncertainties and other vulnerabilities is the prevalence of multiple hazards in the region. These hazards include the presence of endemic epidemics, pest attacks, and monsoon-related flooding. For instance, the medical statistics of the district show that there has been an alarming rise in the incidence of diseases such as diarrhea, acute respiratory infections, pneumonia, viral hepatitis A, pulmonary tuberculosis, chikungunya and dengue. Days before the onset of the landslides, the livelihoods of the local population were severely paralysed by various epidemics in the study region. On the contrary, there is only one primary health centre with one doctor and zero in-patient facilities in the Panchayat.

\section{Discussion}

The political economy perspective on disasters has certainly helped us to understand the factors that influence the progression of vulnerability to disasters. In this regard, the Pressure and Release model is a suitable model to explain the progression of vulnerability. It could be seen that the historically specific lack of access to power, decision making and access to resources remain the root causes of vulnerability. There are various dynamic pressures acting on the root causes such as the larger integration of the fragile agrarian economy into the global market, severe environmental degradation, and ineffectiveness of local level institutions to address risk reduction. These dynamic pressures have acted upon the root causes leading to the manifestation of several unsafe conditions such as habitats in hazardous locations, insecure livelihoods, weak social links (due to the migration), and poor disaster preparedness by the state mechanisms. The progression of vulnerability is depicted in Figure 6.

Nevertheless, one significant observation is that the relationships between the root causes, dynamic pressures and unsafe conditions are not as purely linear as they appear. These relationships are highly time-space dependent, and to be more specific they are historically rooted. On the other hand, any attempt to address the historical specificity should in turn take into consideration the economic and environmental dynamics rooted in the present patterns of mainstream development. Thus, vulnerability reduction in practice becomes very complex. Moreover, the absence of historically- rooted, holistic approaches to vulnerability reduction actually has the potential to create/re-create new forms of vulnerability. This paper asserts that neither a vibrant civil society nor decentralized governance alone could ensure a disasterresilient society; instead it argues that any good governance process should incorporate vulnerability reduction as one among the key goals to prevent disasters.

In addition, this paper argues that the present approaches to address vulnerability in the region fail to recognise the complexities of population vulnerability to multiple hazards. The popular assumption is that natural hazards act in a linear fashion and therefore disaster response and risk reduction strategies could be crafted or formalised based on standard assumptions. Moreover, the intensity (of impact) of a particular hazard will actually be manifested when another hazard acts upon it. For instance, many households in the region would have considered the outbreak of the epidemics as a common, monsoon-related illness and would have believed 
Fig 6: Modified from Pressure and Release (PAR) Model THE PROGRESSION OF VULNERABILITY

\begin{tabular}{|c|c|c|c|}
\hline Root Causes & Dynamic Pressures & Unsafe Conditions & Hazards \\
\hline $\begin{array}{l}\text { Limited access to } \\
\text { - Political Power } \\
\text { - Decision-making } \\
\text { structure } \\
\text { - Resources } \\
\text { - Information } \\
\text { Ideologies } \\
\text { - Top-bottom } \\
\text { approaches in } \\
\text { governance } \\
\text { - Growth-oriented } \\
\text { development } \\
\text { - Highly integrated to } \\
\text { the global market }\end{array}$ & $\begin{array}{l}\text { Micro-forces } \\
\text { Lack of } \\
\text { - Local institutions in } \\
\text { managing the } \\
\text { environment } \\
\text { - Local community } \\
\text { participation in town } \\
\text { planning } \\
\text { - Local investments in } \\
\text { environmental } \\
\text { management } \\
\text { - Adherence to } \\
\text { environmental } \\
\text { standards } \\
\text { - Public awareness } \\
\text { - Declining bio-diversity } \\
\text { - Accountability } \\
\\
\text { Macro-forces } \\
\text { - Demographic changes } \\
\text { - Deforestation } \\
\text { - Decline in soil } \\
\text { productivity } \\
\text { - Decline in quality of } \\
\text { commons } \\
\text { - Globalisation and } \\
\text { vulnerability of local } \\
\text { markets }\end{array}$ & $\begin{array}{l}\text { Physical Environment } \\
\text { - Settlements in hazardous } \\
\text { locations } \\
\text { - Fragile food/eco-system } \\
\text { chains } \\
\text { - Misuse of commons } \\
\text { - Water pollution } \\
\\
\text { Public action and } \\
\text { institutions } \\
\text { - Poor social protection } \\
\text { - Lack of/inadequate } \\
\text { warning } \\
\text { - Excluded from hazard } \\
\text { protection } \\
\text { - Lack of social and } \\
\text { ecological security } \\
\text { - Lack of livelihood } \\
\text { security } \\
\text { Local Economy } \\
\text { - Livelihoods at risk } \\
\text { - Lack of insurance against } \\
\text { disasters } \\
\text { - Resource-exploitative } \\
\text { technology and networks } \\
\text { - Lack of appropriate } \\
\text { technology } \\
\text { Social Relations } \\
\text { - Special groups at risk } \\
\text { - Lack of local institutions }\end{array}$ & Elooding \\
\hline
\end{tabular}

Source: Wisner et al. (2004)

that it would not affect their livelihoods for a long-period of time (a kind of coping strategy). However, they would have realised the actual impact of the epidemics after the occurrence of landslides and resultant loss of livelihoods.

The complexities of the event also increased with the onset of secondary hazards such as flash floods, which submerged the huts and vegetation on the riverbanks. The crisis worsened as the events happened at night time, when most of the population was sleeping. However, the analysis of vulnerability would not be complete, if we limited it to the mere onset of physical events such as landslides and flash floods. These hazards had actually impacted upon a 
population which was still recovering from the after-effects of epidemics such as chikungunya and other viral fevers. It was observed that at least one member in every household, including the elderly and children, were affected by the epidemics. This also implies that the livelihoods of many poor people in the village were affected even before the onset of the landslides and flash floods. From the viewpoint of sustainable livelihoods, the landslides actually acted upon on an already ailing population deprived of good health and regular, secure livelihoods. Moreover, there was a threat of new epidemic outbreaks after the landslides due to the contamination of water resources.

The role of environmental vulnerability to disasters and its impact on the livelihood of the local population can never be disregarded. However, the present case shows that very few actors involved in decision-making and implementation are concerned about the intricate linkages between environmental degradation and disaster risk reduction. Despite the environmental implications of disaster risk and vulnerability, the links between environmental degradation and disasters have long been ignored.

To conclude, this paper raises the following questions that are very crucial indicators in disaster risk reduction:

(a) Is development planning at the local, regional and national level taking into account the need to reduce vulnerabilities?

(b) Are the efforts to reduce vulnerabilities addressing the historical and contemporary dimensions of social, economic and political oppression?

(c) Are attempts aimed at disaster preparedness addressing livelihood securities, specifically with respect to the physical, natural, social, financial and human capital?

(d) Are the three actors in governance, namely the state, civil society, and the market giving serious emphasis to the linkages between environmental planning and disaster risk reduction?

(e) Are the existing models of vulnerability reduction capable of dealing with multiple hazards at the same time?

(f) How far are local knowledge and coping capacities enabling the evolution of a disaster resilient community? How are formal interventions of risk reduction affecting the locally evolved systems and practices, and vice versa?

This paper has attempted to highlight the significance of the above-mentioned dimensions in disaster risk reduction. Though it does not aim at providing concrete solutions or clear-cut strategies, these insights act as indicators or checklists for better implementation. Moreover, these questions could aid in generating new research, supplementing debates and strategies to reduce vulnerabilities and disaster risk in different parts of the world. 
Population vulnerability and disaster risk reduction: A situation analysis among the landslide affected ...

\section{References}

CANNON, T., TWIGG, J. \& ROWELL, J. 2003. Social vulnerability, sustainable livelihoods and disasters. Report to DFID Conflict and Humanitarian Assistance Department (CHAD) and Sustainable Livelihoods Support Office. [Web:] http://www.abuhrc.org/Documents/Social_vulnerability_sust_ live.pdf [Date of access: 19 Mar. 2010].

CENSUS OF INDIA. 2001. Panchayat-wise population Kerala, Thiruvananthapuram: Directorate of Census Operations.

GOVERNMENT OF KERALA. 2004. Economic review 2004: Environment. Department of Planning and Economic Affairs. [Web:] http://www.kerala.gov.in/dept_planning/er/chapter6.pdf [Date of access: 19 Mar. 2010].

KRISHNAN, J. \& GEORGE, A. 2009. Ecology and equity in rights to land and water: A study in south eastern Palakkad in Kerala. Water Alternatives, 2(1):1-15, Feb. [Web:] http://www.water-alternatives.org [Date of access: 19 Mar. 2010].

KUMAR, B.M. 2005. Land use in Kerala: Changing scenarios and shifting paradigms. Journal of Tropical Agriculture, 42(1-2):1-12 http://www.jtropag.in/index.php/ojs/article/viewFile/136/130 [Date of access: 19 Mar. 2010].

LEWIS, J. 1999. Development in disaster prone places: Studies of vulnerability. London: Intermediate Technology Publications. $224 \mathrm{p}$.

MOHANKUMAR, S. \& SHARMA, R.K. 2006. Analysis of farmer suicides in Kerala. Economic and Political Weekly, 41(16):1553-1558, 22-28 Apr.

RADHAKRISHNAN, P. 1982. Land Reforms and Changes in Land System: Study of a Kerala Village. Economic and Political Weekly, 27 (39):117-119, 25 Sep

SANTHA, D.S. 2008. Environmental governance and disaster risk reduction: Re-imagining publicprivate partnerships. (In Centre for Public Policy. Public private partnerships and urban governance: Papers read at the Third Annual CPP International Conference on Public Policy and Management held in Bangalore on 03-06 August 2008.)

SANTHA, D.S. \& BHUVANESWARI, S. 2009. A malady amidst chaos: Examining population vulnerability to chikungunya epidemic in Kerala, India. Loyola Journal of Social Sciences, 23(2):111-129, Jul.-Dec.

UNISDR (United Nations International Strategy for Disaster Reduction). 2004. Living with risk: A global review of disaster risk reduction initiatives. Geneva: UN Publications. 429 p.

WISNER, B., BLAIKIE, P., CANNON, T. \& DAVIS, I. 2004. At risk: Natural hazards, people's vulnerability, and disasters. London: Routledge. $471 \mathrm{p}$. 